\title{
Characterization of di-RuPOM
}

\section{X-ray Diffraction}

XRD measurements were carried out on six unique samples. These results can be summarized as follows. Single crystal X-ray diffraction studies reveal two $\alpha-\mathrm{B}-\left[\mathrm{ZnW}_{9} \mathrm{O}_{34}\right]^{12-}$ units linked by a four metal atom belt as shown in Figure 1 of the ms. The two lobes of the cluster are related through a center of inversion. The four atom belt consist of two zinc centers that are bound in five positions by the two $\alpha-\mathrm{B}-\left[\mathrm{ZnW}_{9} \mathrm{O}_{34}\right]^{12-}$ fragments, and in their six site by a coordinating water molecule. $\mathrm{W}$ and $\mathrm{Ru}$ atoms that are disordered by the inversion center occupy the remaining two positions. In addition, refinement on the occupancy of this site reveals an excess of $\mathrm{Ru}$ in the belt corresponding to $\left[\mathrm{W}_{0.76} \mathrm{Ru}_{1.24} \mathrm{Zn}_{2}\left(\mathrm{H}_{2} \mathrm{O}\right)_{2}\left(\mathrm{ZnW}_{9} \mathrm{O}_{34}\right)_{2}\right]^{14-}$. This indicates that there is some compositional variation in the clusters and demonstrates unambiguously that di-ruthenium clusters exist in the product mixture. Analogous compositional variations were observed in $\left[\mathrm{WMZn}_{2}\left(\mathrm{H}_{2} \mathrm{O}\right)_{2}\left(\mathrm{ZnW}_{9} \mathrm{O}_{34}\right)_{2}\right]^{12-}(\mathrm{M}=\mathrm{Co}, \mathrm{Zn})$, where excesses of $\mathrm{Co}$ and $\mathrm{Zn}$ were found. ${ }^{1}$

\section{Elemental analysis}

Elemental analysis determinations were made using energy dispersive X-ray (EDX) spectroscopy carried out on the same single crystals that were used for the XRD measurements discussed above. For each single crystal sample, three iterations were performed and the results for all samples were pooled. Quantitation was carried out for $\mathrm{Na}, \mathrm{Ru}, \mathrm{Zn}$ and $\mathrm{W}$. In the table below, averaged experimental data are compared to values calculated using the formulation $\mathrm{Na}_{14}\left[\mathrm{Ru}_{2}^{\mathrm{III}} \mathrm{Zn}_{2}\left(\mathrm{H}_{2} \mathrm{O}\right)_{2}\left(\mathrm{ZnW}_{9} \mathrm{O}_{34}\right)_{2}\right]$.

\begin{tabular}{|l|l|l|l|}
\hline Element & Calc weight \% & Exptl weight \% & Exptl mol \% \\
\hline $\mathrm{Na}$ & 6.17 & 5.80 & 25.22 \\
\hline $\mathrm{Ru}$ & 3.88 & 3.79 & 3.75 \\
\hline $\mathrm{Zn}$ & 5.01 & 4.92 & 7.52 \\
\hline $\mathrm{W}$ & 66.40 & 64.03 & 34.84 \\
\hline
\end{tabular}

The experimental $\mathrm{W} / \mathrm{Zn}$ and $\mathrm{Zn} / \mathrm{Ru}$ molar ratios are 4.63 and 2.01, respectively. These compare well with the above formulation, for which $\mathrm{W} / \mathrm{Zn}=4.50$ and $\mathrm{Zn} / \mathrm{Ru}=2.00$. The predicted $\mathrm{W} / \mathrm{Zn}$ molar ratio for Neumann's formulation (ref. 2) $\left(\mathrm{Na}_{11}\left[\mathrm{ZnWRu}_{2}(\mathrm{OH})\left(\mathrm{H}_{2} \mathrm{O}\right)\left(\mathrm{ZnW}_{9} \mathrm{O}_{34}\right)_{2}\right)\right.$ is 6.33, while the $\mathrm{Zn} / \mathrm{Ru}$ molar ratio is 1.5 . 


\section{FTIR spectroscopy}

FTIR of RuPOM 2

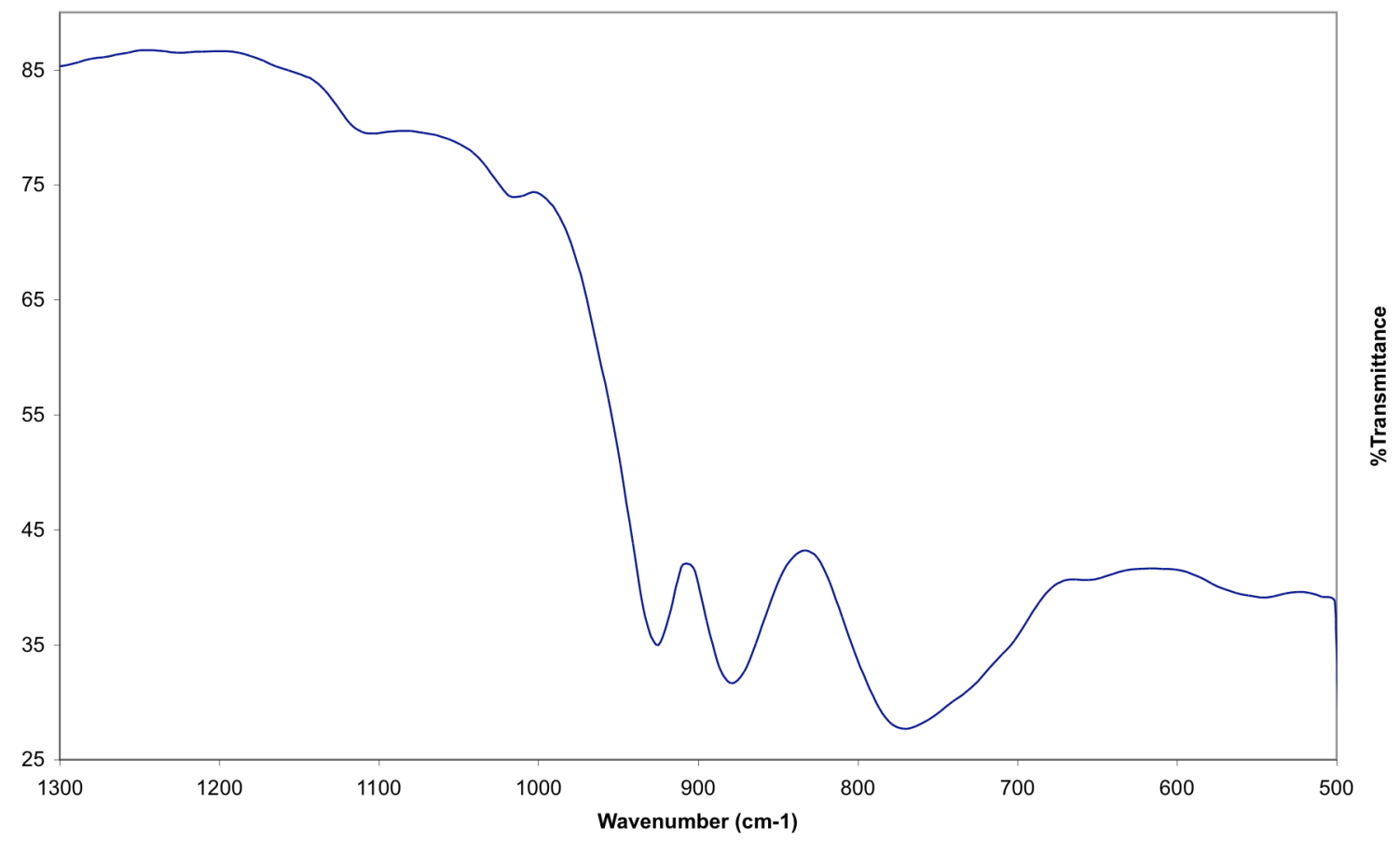

\section{$\underline{\text { References }}$}

1. Tourné, C. M.; Tourné, G. F.; Zonnevijlle, F. J. Chem. Soc. Dalton Trans. 1991, 143.

2. Neumann, R.; Khenkin, A. M. Inorg. Chem. 1995, 34, 5753. 